\title{
Development of Regional Economics Studies in Peru: Contributions and Criticisms
}

\author{
Juan Palomino ${ }^{\mathrm{a}}$ \\ 0000-0003-2828-8424 \\ a Department of Economics, PUCP, Lima, Perú \\ $\bowtie$ juan.palominoh@pucp.pe
}

\begin{abstract}
This research presents an overview of the evolution of regional economic studies in Peru. After a brief introduction, the document presents a summary of the different conceptions of space in Regional Economics through time. In addition, the document shows the origins of Regional Economics, as well as the factors that explain the interest in the development of regional studies in the Latin American context. This document also explains the importance of the geographical space of Peru for regional research. Indeed, the country is the perfect setting because Peru has a wide geographic diversity (ecosystems, microclimates) throughout its territory, it has implemented a variety of public policies to propose economic growth measures, and it has many social issues to propose territorial policies (migration, crime, health, employment, among others). Despite these characteristics, regional research in Peru is relatively less than in other Latin American countries. Finally, the document offers the contributions and criticisms of the regional studies in the Peruvian context.
\end{abstract}

Article History: Received: March 302020 / Revised: August 102020 / Accepted: August 132020 Keywords: Regional economics; Regional studies; Space; Geography; Regional growth and development; Peru.

JEL Classification: R10, R12, R50

\section{Acknowledgements}

The author would like to thank the Editor-in-Chief, Gabriel Rodriguez, and an anonymous referee for their valuable comments. Any remaining errors is my responsibility. 


\section{Introduction}

In the last two decades, Regional Economics studies have been characterized by exciting new developments, marked by a growing trend over time, which has allowed to position itself as one of the main branches of the Economics. Currently, many researchers and analysts think that the Regional Economics is the analysis of economic activities or social phenomena at a given administrative territorial level (regions, provinces, municipalities) as is often presented in several studies. However, the Regional Economics is a branch of the Economics where the main component is the spatial dimension, that is, it is the study of how space affects the economic behavior and operation of markets; see Capello (2009). For example, how population and employees are spatially located in small or large concentrations, how regions develop within a country, how transport plays an essential role in the spatial structure of an economy, how location affects international trade or even know the relevance of gender in territorial development.

Historically, the territorial approach had always been a subject of exclusive interest to geographers. However, in the 1950s in the United States, the interest of various professionals (economists, political scientists, sociologists, historians) to provide new theoretical and methodological perspectives to analyze space in territorial and urban planning, encouraged the creation of the Regional Science by Walter Isard. Subsequently, the interests to develop regional studies were promoted by New Economic Geography of Krugman (1991).

Likewise, in Latin America, the emergence of regional studies has come more from the historical economic and social context that Latin countries have suffered, such as economic inequality, poverty, agrarian reforms, migration, among other issues. This has attracted more attention from international organizations (World Bank, CAF, ECLAC) and policy makers. Moreover, innovation in technological tools such as georeferenced information software, open data portals, greater availability of information at the subnational level has been a support to carry out a better analysis of an economic, social, geographical and environmental phenomenon within a territory.

In that sense, Peru is the perfect setting for conducting studies with a spatial component for a number of different reasons. From an administrative perspective, the Peruvian territory is divided into 24 departments, 196 provinces, and 1874 districts, which makes it interesting to explore various cases at the subnational level. From a geographical perspective, Pulgar Vidal (1946) has divided Peru into 8 natural regions, differentiated by altitude, the variety of ecosystems, different species of flora and fauna, and the diversity of climates throughout its territory; see MINAM (2014). This means that Peru has a great variety of mineral reserves such as silver, tin, copper, gold, etc. Figure 1 represents these 8 natural regions within the 24 departments of Peru.

From an economic point of view, public policies have been implemented in Peru to propose fiscal decentralization measures and generate new engines of economic growth that lead to the improvement of productive diversification at the regional level. From a social perspective, there are issues such as migration, crime, health, employment, among others that are interesting to address from a spatial approach. However, given these geographical, economic and social characteristics that are favorable for developing new topics with a territorial and spatial approach, 


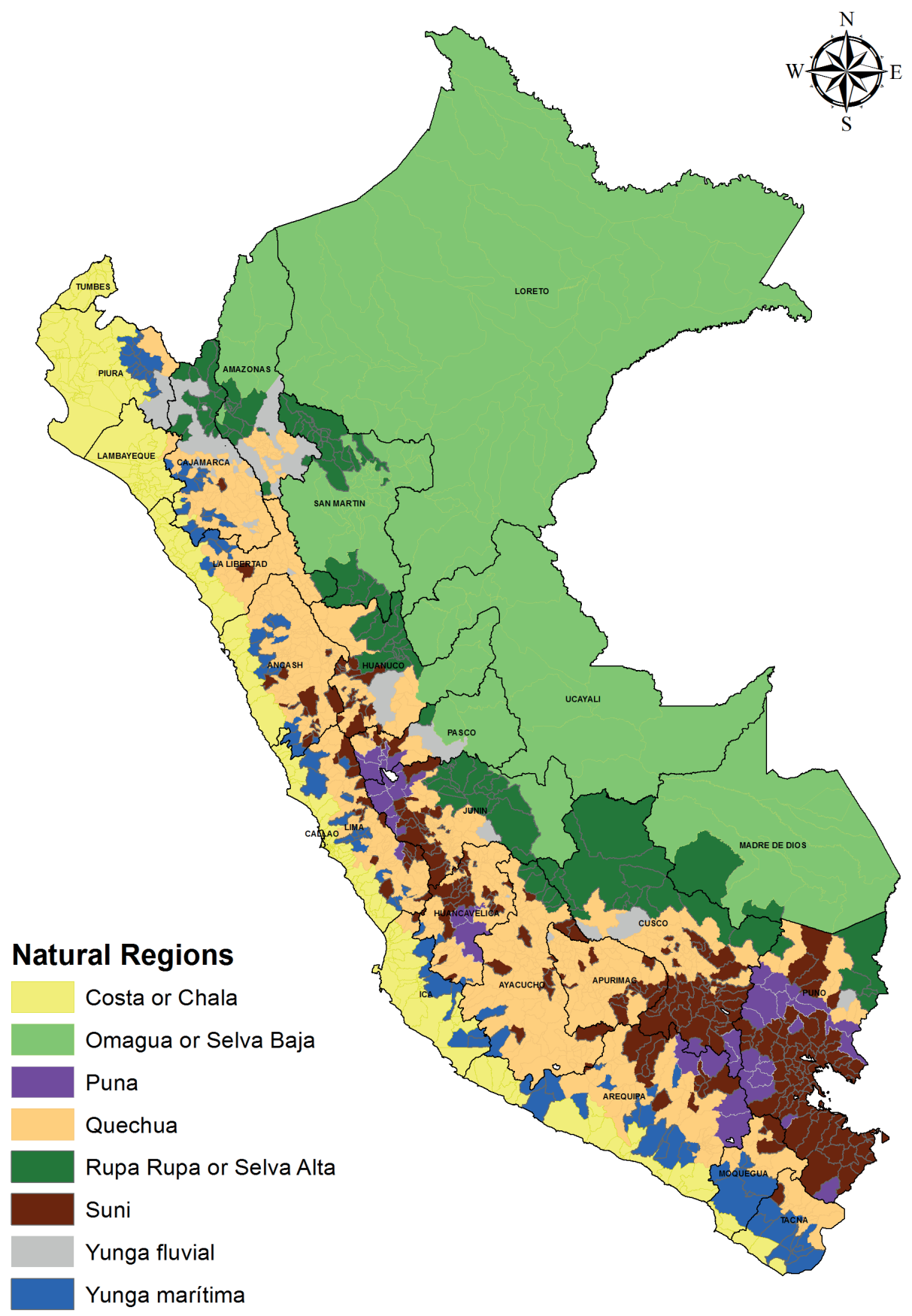

Note: The territory of Peru is divided into 24 regions (regiones), 196 provinces (provincias) and 1874 districts (distritos). Own elaboration based on INEI 2018.

Figure 1. Natural Regions of Peru (2018). 
the amount of research is still scarce, and progress is still relatively less compared to other Latin American countries such as Chile, Brazil, Mexico and Ecuador. These countries have regional research groups and postgraduate programs in Regional Economics and Spatial Econometrics to develop regional studies.

Therefore, the objective of the document is to provide an overview of regional studies in Peru and, at the same time, show what has been advanced and provide constructive criticism of what can be developed in the future. The analysis of these issues will allow establishing longterm territorial cohesion strategies so that all Peruvian territories can express their development potential and none of them are persistently marginalized. It should be noted that some of the regional studies that have been developed in Peru are mentioned, however, it is practically inevitable to omit some texts.

According to the above, the article is organized as follows. Section 2 provides an overview of the Regional Economics and the different conceptions of space in the international arena. Section 3 presents the emergence of interest in regional studies in the Latin American context. Section 4 provides evidence of the development of the regional studies in Peru. Finally, Section 5 discusses the main reflections and conclusions.

\section{The Rise of Regional Economics}

This chapter summarizes the arduous path that regional economics had to integrate and position itself as one of the main branches of Economics. It also narrates the different conceptions of space that have emerged in the literature of regional studies.

To begin with, the possibility of addressing location problems in economics appears for the first time in studies of neoclassical theory. For example, in the study of Marshall (1920), the exclusion of the conception of space is evident with the following phrase: "The difficulties of the problem depend chiefly on variations in the area of space, and the period of time over which the market in question extends; the influence of time being more fundamental than that of space". Indeed, contemporary researchers have followed the neoclassical approach, and there is an abundance of empirical studies on dynamic models with the illogical assumption that all producers, consumers, inputs, and products are located in a single point of the market.

This abandonment of territorial issues by the most renowned economists lasted until practically between the '40s and '50s of the 20th century, when some economists began to feel dissatisfied with the low level of regional economic analysis and felt the need to relate geography and economy. Thus, Walter Isard, in 1956, highlights a leading role in integrating studies of economists, geographers, and urban planners in a science called Regional Science; see Boyce (2003). This marked a milestone in regional studies since the conception of space in economics was expanded. However, these studies received much criticism, particularly for the tendency towards highly theoretical aspects, which were detached from what the policymakers required; see Isserman (1995). Therefore, new regional research emerged on an international scale, which allowed the development and positioning of Regional Economics within Economics. Then, the

\section{(c) PUCP}


conceptions of space over time are summarized below. ${ }^{1}$

First of all, it is not until the arrival of the subjects of localization of economic activities found in Von Thünen's models of concentric rings (Sinclair, 1967) and the models of the central business district (Alonso, 1964) that the first takeoff of regional economics occurs. In location theory, the conception of space is "physical-metric" since it plays the role of a physical barrier between economic activities; that is, it takes the form of a physical distance between the input and product markets. This physical distance in the models is conceptualized through transportation costs.

Second, new theories of regional growth emerged in the 1950s and 1960s, using a concept of space as "uniform-abstract". In this case, the researchers understand space as administrative territories - a region, a province, a municipality - to develop economic activities and create conditions for permanent development. The advantage of this conception is that it allows the use of economic models to interpret the phenomenon of regional growth (Hoyt, 1954), the theory of export base (North, 1955; Tiebout, 1956), and the theory of interregional trade (Heckscher, 1919; Ohlin, 1935).

Third, a new trend emerges with theories of regional development in the 1970s, which conceive space as a source of increasing returns and positive externalities in forms of agglomeration and location economies; see Perroux (1970). These theories postulate that regional development depends on the efficiency of a region over its concentrated production, and not on the availability of economic resources. Therefore, space is conceived as "diversified-relational", a diversified space in which there are many economic activities; however, development will occur if the region presents a concentrated organization of its production. It is also relational since, in this space, social and economic relationships that are key to obtaining a competitive advantage of the region over others are produced. Likewise, a competitive advantage of a region is produced, from which the proper functioning of market mechanisms, an accumulation of knowledge in the local market, and an improvement in the innovation of products and services are highlighted.

Finally, in the late 1980s and early 1990s, a new reconsideration of the different economic problems arose in relation to the location of productive activities, the effect of agglomeration, and the displacement of factors of production; see Capello (2009). These questions allowed a new conception of space, called "diversified-stylized". The logic in this conception is that there is a diversification of productive activities within a region, which allows the existence of agglomeration economies. However, relationships within these areas remain abstract in nature. This conception is born in the endogenous growth models (Romer, 1986) and the new economic geography (Krugman, 1991).

Additionally, it is necessary to refer to the derived studies that were born from Regional Economics, one of which is Urban Economics. It has paved the way to the exploration of topics on urban growth, urban commutation, transport issues, analysis of spatial interdependence, or the analysis of the relationships that exist between growth, environment, and territory. Consequently, from the beginning of the 20th century until today, new regional studies have emerged thanks to the technological boom of the internet, big data, and artificial intelligence. These

\footnotetext{
${ }^{1}$ For more discussion on the different conceptions of space, see Capello (2009).
} 
new tools provide georeferenced information on various spatial phenomena that can be captured in a Geographic Information System (GIS). This allows the use of analysis and spatial econometrics to explore and evaluate the impact of a certain economic phenomenon on the regional economy. One of the pioneering studies in this branch of spatial econometrics is that of Paelinck (1978); later this branch is developed by two different approaches: Anselin (1995) and LeSage (1997). Even though they are two schools of spatial econometrics with a different focus on their interpretation, they have allowed the development of new spatial techniques in various fields of economics.

Finally, it should be mentioned that the take-off of regional economics would not have been possible without the interest of creating two international organizations, called the Regional Science Association International (RSAI), founded in 1954, and the Regional Studies Association (RSA), founded in 1965, which annually bring together various economists, geographers, and urban planners to discuss issues with a spatial focus in various parts of the world; see Capello (2009). Likewise, the role that international organizations and universities have had in recent years to promote regional research should be highlighted. Hand in hand comes the high number of specialized scientific journals that provide a contribution and open a path to the development of new regional studies. Added to all this is the fact that regional problems and territorial policies to solve them are currently listed in the political programs of many governments. This current situation is the best testimony that we have at present about the development of regional studies compared to what existed in the fifties of the last century.

\section{The Interest of Regional Studies in the Latin American Context}

Regional studies in the Latin American context had a very different origin from the regional studies that emerged in the United States. As mentioned above, regional studies in North America were promoted by a current called Regional Science since the 1950s. In later decades, a strong contribution of studies with a regional focus became visible, especially due to the emergence of the New Economic Geography, which marked a milestone and an advance to the development of more regional studies.

In the case of Latin America, the story is quite different. Obviously, in this part of the continent, no currents were formed in the 1950s to carry out research in this regional field. The contribution of universities and organizations was minimal in terms of regional research. In fact, the emergence and interest in regional studies in Latin America comes from the economic history that each country experiences. The economic history of Latin American countries is framed by a set of similar problems such as regional inequality, poverty, informality, fiscal decentralization, urban problems, interregional migration, concentration of population in metropolises, cultural diversity, among others.

Delving a little deeper into economic history, in the 1950s and 1960s, the Latin American economic context was built by recommended policies of the Economic Commission for Latin America and the Caribbean (ECLAC). One of those measures was the development of local industries through import substitution: Latin American countries substituted the products they

\section{PUCP}


imported, particularly goods, with products manufactured in the country; see Cuadrado-Roura and Aroca (2013). The problem was that this model only benefited developed countries since they exported manufactured goods, while Latin American countries exported agricultural and mineral products. Obviously, the Latin American economy declined over time. As a consequence of these measures, some agrarian reforms occurred to prevent land ownership from being held by a concentrated group; see Bonzanini et al. (2018).

In the 1960s, governments played a more fundamental role with political reforms that promoted greater equality and affected the interests of multinationals. This led to a significant decrease in local investment, which triggered the implementation of regional policies to finance the growing product demand. However, the results led to stagflation of the economy in many countries; see Di Filippo (2019). In the early 1970s, stabilization measures were applied in Latin America, such as the contraction of budget deficits, which were accompanied by military dictatorships. Obviously, this brought positive control over existing inflation, but it did not generate economic growth in Latin America.

The decade of the '80s, known as "the lost decade of Latin America", marked a turning point in Latin American history because many economic and social coups occurred (terrorism, attacks, among others); see Lustig (2010). In this decade, policies were presented to reduce spending aimed at the poorest sectors, which caused an increase in territorial inequalities within each country. Later, in the 1990s, there were signs of economic and social recovery in these countries. Governments implemented neoliberal policies and decentralization plans to guarantee the reduction of inequality; see Gasparini and Lustig (2011). However, these strategies did not work in some countries, and that is the reason why fiscal and economic decentralization continues to exist in most countries today, making the wide gap of economic inequality between different regions of a country evident.

From this Latin American context, interest to understand the regional problems within each country arises for various researchers. For example, Chile is characterized by having a large territory that goes from the desert north to the Antarctic pole, which entails a wide diversity of geography. However, despite this diversity, $80 \%$ of the population is concentrated in urban territories settled in the Santiago Metropolitan Region; see Frigolett (2013). On the other hand, Chile has shown remarkable economic growth in the last decades and has been particularly successful in reducing poverty during the last decade, going from $29.1 \%$ in 2006 to $10.9 \%$ in 2017; see MINDES (2019). However, regional inequality persists over time and continues to be one of the highest in the world; see Contreras et al. (2001); Paredes et al. (2016).

In addition, Chile is characterized by being an extractive economy in mining, agricultural and fishing activities. An interesting case is the region of Antofagasta, located in northern Chile where copper and lithium mining deposits are located. In this region, there is a phenomenon called "work commute", which is the displacement carried out by workers who live in regions different from the ones where they work. This region represents around $60 \%$ of GDP and receives $16.81 \%$ of the total commuters in Chile and more than $10 \%$ of its workforce live in other regions; see Aroca and Atienza (2011). Consequently, this mining region is considered an enclave since, despite its greater participation in the country's economic production structure, there has been 
no economic development in the quality of life of its citizens; see Arias et al. (2014).

Another case is Colombia, which is characterized by having one of the worst income distributions at the regional level; see Bonet and Meisel (1999). Over the past three decades, inequality has increased, and the most impoverished areas, such as the Caribbean and Pacific coasts, have not received special support from the central government policies. Furthermore, what is observed in the Colombian context is an increasing territorial polarization in which the economic disparities between the main cities have been increasing over time; see Galvis and Meisel (2001). For instance, Bogotá is a city that has achieved economic importance at the national level, and it is oversized in relation to the rest of the country. Consequently, the other cities depend economically on the main city since the most important economic opportunities are concentrated there. Also, investment and urban infrastructure strengthen the ability to undertake projects, making this city more attractive.

Another explanation for the ongoing growth of regional economic disparities in Colombia are the "spatial poverty traps", where poverty conditions are limited to specific geographic areas; see Durlauf (2006). In these areas, poor local economies may have low-quality education that remains static for years, implying a reproduction of poverty from generation to generation; see Benabou (1996); Galvis and Meisel (2013). This process would imply not only the persistence of disparities but also the polarization of regional economic growth.

A similar case is the economy of Mexico, which is characterized by strong economic and social contrasts throughout its territory, where dynamic regions coexist, characterized by the productive diversification of their economic activities and regions that present strong economic lags; see González et al. (2010). In this sense, the regional studies found the most in the Mexican literature revolve around regional convergence, characterized by identifying the factors associated with growth. For example, Katz (1998) evaluates the distribution of per capita income among Mexican states after the processes of trade liberalization, finding that there is a concentration of income in the metropolitan cities of Mexico City, Guadalajara, and Monterrey. Another study is about the impact of the free trade agreement on the dynamics of regional inequalities in Mexico, where it was shown that the northern regions have benefited from a large concentration of manufacturing production; see Messmacher (2000); Calderón and Mendoza (2005).

Furthermore, in Mexico there has been an impulse for the development of studies focused on the use of new techniques for spatial analysis and identification of clusters. For example, Asuad et al. (2007) evaluate regional convergence with models of spatial econometrics, finding that there are convergence clubs in the central region of the country. Sastré-Gutiérrez and Rey (2008) show that regional divergence is related to the existence of regional polarization. Furthermore, these regional disparities have been associated with the existence of poverty traps and spatial inequality, which have repercussions on economic development. Therefore, although changes have occurred at the intraregional level, derived from economic liberalization and the external orientation of the economy, they have not been strong enough to solve the structural problems of regional and urban development in Mexico.

Therefore, a fact to be highlighted is that Latin America has literature about regional studies that has been growing in recent decades, but unlike Europe and the United States, it is still 
expanding. In summary, factors that have fueled this growth in regional studies are the following:

1. First, the strong interest of international organizations to pay more and more attention to the growth of territorial inequalities. For example, CEPAL (2009) has shown that the regions are classified as laggards and winners. However, it is noticeable that most of the studies focus on the dynamics of GDP at the regional level and ignore the use of other multidimensional indicators and how that affects the well-being of different territories of the countries. As for the World-Bank (2009), it has proposed policies that generate concentration or increase density in various cities in Latin America, based on studies of the New Economic Geography. Moreover, the OECD (2009) has referenced the Chilean case as a simile for other countries since it needs to reduce concentration in the metropolitan area and make better use of its regional assets. Lastly, CAF (2010) shows that regional policy and development are key to promoting the productivity of companies and improving the quality of life of inhabitants in a city or region.

2. Secondly, there has been an enormous production in the theoretical field, with the sophistication of microeconomic models that can be abstracted from reality; and in the empirical field, thanks to the computational development of new techniques: from regional inputproduct matrices to the use of spatial analysis techniques, spatial econometrics, and the use of geo-referenced information systems to analyze Latin American issues with a regional focus.

3. Finally, the concern of governments in Latin America for generating territorial policies on various topics has grown. The topics include territorial cohesion, regional growth and its causes, urban or transport problems, the agglomeration of companies, the segmentation of markets, problems of interregional migration, and environmental problems, in particular, the impact generated by extractive activities at the local level.

\section{The Path of Regional Studies in Peru}

Regional Economics studies in Peru have shown an increasing trend over time, but it is still slow compared to other Latin American countries. When analyzing the introduction of the spatial concept and regional theories, as well as the production of economic studies dedicated to territorial issues, the antecedents are quite scarce. In fact, the starting point for the growing interest of Peruvian economists in territorial issues may be located in the early ' $80 \mathrm{~s}$. At this time, the interest to understand and rethink the regional problem in Peru was awakened, see Gonzales de Olarte (1982); it tried to reflect on whether the economic structural problem in the regions was the way of organizing production, circulation, and distribution in said territory. However, there is a temporary space in the '90s where studies with space techniques are not carried out.

In spite of this, one of the most prominent themes observed in the regional literature of Peru is economic convergence and the proposal of macro-region constructions; that is, if, from similar characteristics between the regions, they can be grouped with the purpose of proposing political 
improvements. Among these studies, the ones by Gonzales de Olarte and Trelles Cassinelli (2004); Sutton et al. (2006); Delgado and Del Pozo Segura (2011); Delgado and Rodríguez (2015, 2017) stand out. These investigations have tried to estimate convergence rates of GDP per capita between different regions; that is, whether there is a point of long-term convergence among all of them. Likewise, the convergence analyses have innovated with the use of spatial econometric techniques that have been applied to this topic. For example, Palomino and Rodríguez (2019) analyze the convergence of GDP per capita of the 24 regions of Peru in the period 1979-2017 using spatial econometric models, which allows obtaining direct and indirect spillover effects. One of the results to be highlighted is the proposal for the existence of four space clubs. The first club is represented by highly productive and dynamic regions (Lima and Moquegua). The second club is made up of regions with low productivity (Amazonas, Loreto, and Madre de Dios). The third club is made up of moderately productive regions (Áncash, Arequipa, Ica, Junin, Lambayeque, La Libertad, Puno, Tacna, and Tumbes). The fourth club is made up of stagnant regions (Apurímac, Ayacucho, Cajamarca, Cuzco, Huancavelica, Huánuco, Pasco, Piura, San Martín, and Ucayali). In summary, the authors conclude that economic policies should aim that the central government should pay special attention to the most disadvantaged groups of sub-national governments in terms of GDP per capita.

Furthermore, there has been an incipient but growing concern about the unfinished process of fiscal decentralization in Peru, which has left regional governments with extremely weak autonomy of spending and income. For example, in 2004, there was a referendum to decentralize functions and transfer spending responsibilities to regional governments; however, it failed. Currently, the regions have little control over the spending functions of education, security, health, and other sectors, which continue to be largely controlled by the central government. The autonomy of regional governments is further compromised by the design of intergovernmental fiscal relations, where the budgets of regional governments are largely financed through discretionary, often politicized, annual allocations by the central government.

One case is mining, where there is a fiscal problem at the municipal level since mining regions receive more resources than they should according to their fiscal capacities and spending needs. For this, there are proposals for studies on the distribution of canon resources at the municipal level. For example, Herrera (2009b) tries to redesign the intergovernmental transfer system at the municipal level, incorporating criteria of horizontal equity and transversal compensation in the distribution of resources. Some of the guidelines for adopting a reform of the intergovernmental transfer system at the municipal level are: (i) the reform of the transfer system should be gradual; (ii) those transfers that impregnate greater inequality in the system must be reformed; that is, there is a need to reform "distorting" transfers in the short term; (iii) consider the local collection capacities as a resource distribution criterion; (iv) establish a scheme of rewards and punishments in the distribution of resources.

In addition to these topics, there are publications corresponding to regional analysis techniques such as input-output tables, shift-share analysis, location coefficients, analysis of urban areas, among others. One study, the structural analysis of the Peruvian economy in the period 1950-2007, carried out by Gonzales de Olarte (2015) stands out. In his study, the author tries to

\section{c) PUCP}


explain how articulated the Peruvian economy is from direct and indirect relationships among productive sectors. Four problems are evident: (a) insufficient supply of the least productive units, (b) dependence on foreign currency to acquire inputs, (c) biases in economic policy, and (d) persistent distributional inequality. Finally, he concludes that while the economic units are heterogeneous and poorly articulated, underdevelopment will be persistent in Peru.

On the other hand, an important part of our current understanding of the fundamental interaction between space and local economic behaviors has its origin in the field of location theory. This consists of the study of where certain economic activities are located and what are the reasons why it is there. Traditionally, the emphasis has been placed on the location patterns of companies and households, but it also includes the study of spatial labor markets and interregional and international migratory flows, including their effects on housing markets. In Peru there is some research on the location and agglomeration of companies.

For example, Herrera (2009a) tries to give an approximation on the most efficient geographical location of Peruvian economic activities. According to him, there are two types of first and second order facilitators that determine this position; the first is one that creates the necessary but not sufficient conditions for the initial establishment of an economic activity (access to infrastructure, institutional environment, regulatory schemes), while the second facilitator acts as a reinforcement and impulse of the processes of primary localization by creating economies of increasing scale (spillover effects, technological innovation, networks). Among the results obtained, it is shown that only $27.5 \%$ of the analyzed municipalities (464 municipalities out of a total of 1,686) have an adequate climate for business development in the country. These municipalities are mainly concentrated in the coastal regions, especially in the municipalities of the regions of Lima and Callao, which have the highest business climate index nationwide.

Another localization study is carried out by Gonzales de Olarte and Del Pozo (2012), in which they investigate the formation of various centers in Metropolitan Lima and the influence they have on the location of businesses and workers. Under the approach of the polycentric model, which establishes several product sales centers and factors that reorganize space, they determine that land rent and capital accumulation are the factors that explain this phenomenon. The authors find ten agglomerations and of these, the Financial Center (CF) of San Isidro, the Shopping Center (CC) of Miraflores, the Mesa Redonda and Mercado Central Shopping Center, and the Commercial and Industrial Center (CI) of Gamarra constitute the main agglomerates because of both their extension and their level of concentration of economic activities.

In Peru, there has also been interest in studies of demographic and migratory changes. According to Yamada (2010), Peru has undergone two great historical processes that have affected society: on the one hand, the constant migration from the countryside to the city; on the other, the irregular periods of growth and economic crisis in the country. One of those periods of economic crisis is mainly due to terrorism caused by "Sendero Luminoso" (Shining Path), which occurred in the south of the country. Additionally, Sánchez (2017) mentions that Peru has become fully urbanized in recent years due to the agricultural crisis and the failed agrarian reform processes, which pressured the increase in internal migration to the capital. In turn, the increase in industry, commerce, more jobs and better wages influenced migration to Lima. 
Therefore, migration has led to increased development dynamics across the country.

Currently, there are studies that evaluate the impact of spatial factors on various socioeconomic indicators. Gonzales de Olarte and Del Pozo (2018) evaluate whether the spatial component is a determinant of the human development of people in Peru. Using spatial econometric models, they find that human development takes place within a socio-spatial context; that is, that it occurs in places that are a combination of geographical conditions, altitudes, urban agglomerations and distances. Therefore, they conclude that space counts to promote or delay human development. For instance, the higher the altitude, the less human development, the greater the size of the city and the closer it is to large cities, the greater human development. They also point out that the human development index is higher on the coast than in the mountains and in the jungle.

Among other social studies, the analysis carried out by Zuñiga and Montalvo (2018) about the spatial dimensions of crime in Metropolitan Lima stands out. The authors focus on the crimes of home burglary and domestic abuse, where they try to answer if the crime is randomly distributed in the districts. Among their results, they show that the characteristics of social disorganization are equally important for both types of crimes but, in the case of domestic abuse, there is a multiplier effect between both characteristics. These results are important since they allow us to identify the places where there is the greatest crime and establish territorial policies on citizen security.

In matters related to health, there is a trend for the geographical distribution of the spread of diseases; however, there are no studies evaluating causal effects. For example, HernándezVásquez et al. (2017) identified regions and district conglomerates with high prevalence of gestational anemia, concentrated in the central and southern part of the Peruvian highlands in 2015 (Huancavelica, Puno, Pasco, Cusco, and Apurímac). Another study by Hernández-Vásquez et al. (2016) found that the regions of Tacna, Moquegua, Callao, Lima, and Ica present the highest prevalence of overweight and obesity at the national level in 2014. In addition, a study by Hernández-Vásquez and Tapia-López (2017) show that, although the prevalence of chronic malnutrition in children under five years of age has decreased by almost six percentage points between 2010 and 2016, high prevalence still persists with a marked inequality of these for 2016, with Huancavelica being the region that persists with a prevalence of chronic malnutrition above $30 \%$.

Finally, the concept of gender in the territorial approach is introduced as a sociocultural system that governs, structures, and enhances the roles and relationships of men and women in each territory; see Paulson (2011). In this sense, when talking about gender in regional studies, it is expected to find huge differences throughout the Peruvian territory. Furthermore, according to Zárate et al. (2015), Peru does not have policies, programs, or experiences that explicitly propose the generation of synergies between territorial development and gender approaches. For example, the productive structure of the jungle has not produced favorable employment conditions for women. In turn, the sociocultural system of the Amazon has also generated that women receive lower incomes, and that they have precarious working conditions, less education, higher infant mortality, among other characteristics. Therefore, it is necessary to evaluate territorial

\section{PUCP}


configurations in order to favor the dynamics of inclusion for women.

In summary, although there is a growing trend in regional studies in Peru in recent decades, the contribution is still scarce. For example, the number of undergraduate and graduate theses that are prepared in the economics schools of the country's universities has a more transversal approach to the impact evaluation of social programs and macroeconomic issues. Likewise, it should be noted that there is no specialized program for regional economics or spatial econometrics in Peruvian universities. This is really critical if regional studies are to be promoted in the country.

In addition, it should be noted that different Latin American countries have research groups with a regional focus. In Latin America there is an organization called "Latin AmericanCaribbean Regional Science Association" (LACRSA), which assigns different organizations dedicated to regional studies of different Latin countries. For example, in Chile there is the Chilean Society of Regional Studies (SOCHER), which has annually brought together economists since 2010 to debate issues with a regional focus. In Brazil there is the Brazilian Association of Regional Studies (ABER), which is a multidisciplinary association of researchers interested in social phenomena and their manifestations in the territory; they also congregate annually. It is worth mentioning that there are other Latin American organizations such as the Argentine Society of Regional Economy (SAER), the Colombian Association for Regional and Urban Studies (ASCER), the Ecuadorian Regional Science Network (RECIR), the Mexican Association of Sciences for Regional Development (AMECIDER), and the Spanish Association of Regional Science (AECR). However, in Peru, there is no organization that brings together regional and spatial studies in Peru. Therefore, it is expected that the regional studies approach will be promoted within the academy.

\section{Conclusions}

In this document, I present an overview of the development of regional studies in the Latin American and Peruvian context in recent decades. Among the main conclusions that can be drawn from this study are the following. First, regional studies have attracted interest from several economists from the contribution of Walter Isard in the fifties, and later with the new wave of studies of the New Economic Geography. These contributions have achieved the following implications: the development of new regional and urban theories; the improvement in the techniques of analysis and spatial econometrics through the use of Geography Information Systems (GIS); and the implementation of territorial policies on various social issues (inequality, poverty, informality, crime, among others).

The second point to highlight is that the development of regional studies in Latin America has a different emergence than that which occurred in the United States, mainly due to historical economic and social factors that occurred in each country during the last 50 years (economic crisis, agrarian reform, informality, economic inequality, terrorism, among others). This rooted the interest of international organizations (ECLAC, World Bank, OECD, CAF, among others) to provide policy recommendations focused on the territory. In this sense, Latin American 
governments have included on their political agenda issues such as the reduction of regional inequality, regional growth, measures to improve transportation infrastructure, among others.

Finally, the third point to note is that, although the development of regional studies in Peru is relatively low in relation to other countries in the region, since the beginning of the 20th century there has been a growth in studies that incorporate the spatial factor. Even so, there is an agenda of topics that can be promoted to develop in territorial aspects. On the one hand, the need to create functional territories, that is, spaces that contain a high frequency of economic and social interactions between workers, organizations and companies. The reason would be to identify functional territories that serve as an instrument to analyze the current behavior of the 1874 districts that make up Peru and that allows to identify, not only, main nodes of development, but also the shortcomings and disadvantages of the districts with a lower level of development.

On the other hand, Peru is a country where inequality is high between the different regions. Therefore, economic policies and decisions by the government should always be included in the agendas of sub-national governments. Among the measures to be implemented are territorial development policies, which are policies aimed at the development of some districts that are lagging behind or that have suffered some type of setback as a crisis in a sector. Likewise, these territorial policies must be long-term, since the development of more backward areas requires profound changes that cannot be achieved through short-term policies. The policy must have continuity, that is, it must not be restricted to electoral processes or changes of government.

Additionally, the academy plays an important role in exploiting the development of regional studies. One of those roles should be the promotion of research with a territorial approach at the undergraduate and graduate levels in universities. Likewise, the creation of research groups for regional studies could help to encourage this type of study. Finally, the need to have data at the district level is necessary and urgent to develop territorial policy. Unfortunately, most of the surveys developed to explore socioeconomic status have inference at the regional level and do not reach the district level. This makes it impossible to carry out studies at the district level with a long period of analysis. 


\section{References}

Alonso, W. (1964). Location and land use. Toward a general theory of land rent. Cambridge: Harvard University Press.

Anselin, L. (1995). Local indicators of spatial association-LISA. Geographical Analysis 27(2), 93-115.

Arias, M., Atienza, M., and Cademartori, J. (2014). Large mining enterprises and regional development in Chile: between the enclave and cluster. Journal of Economic Geography 14(1), 73-95.

Aroca, P., and Atienza, M. (2011). Economic implications of long distance commuting in the Chilean mining industry. Resources Policy 36(3), 196-203.

Asuad, N., Quintana, L., and Ramírez, R. (2007). Desarrollo y políticas regionales en México: Retos y perspectivas 2006-2020. Agenda para el desarrollo. Políticas de Desarrollo Regional 13.

Benabou, R. (1996). Equity and efficiency in human capital investment: the local connection. The Review of Economic Studies 63(2), 237-264.

Bonet, J., and Meisel, A. (1999). La convergencia regional en Colombia: Una visión de largo plazo, 1926-1995. Coyuntura Económica 29(1), 69-106.

Bonzanini, O. A., Diverio, T. S. M., da Silva, L. Z., and Olesiak, E. M. (2018). Economic Development and Dependence Theory: The approach of the UN Economic Commission for Latin America and the Caribbean (ECLAC). Economic and Regional Studies/Studia Ekonomiczne i Regionalne 11(1), 20-33.

Boyce, D. (2003). A short history of the field of Regional Science. Papers in Regional Science 83(1), 31-57.

CAF (2010). Dessarollo Local: Hacia un nuevo protagonismo de las ciudades y regiones. Publicaciones CAF, Caracas.

Calderón, C., and Mendoza, E. (2005). ¿Existen efectos de las remesas y la migración hacia los EE. UU. sobre el crecimiento de México? In J. Aguirre Ochoa and Z. Tamar Infante (Eds.). Remesas y desarrollo en México. México: Instituto de Investigaciones Económicas y Empresariales, Universidad Michoacana de San Nicolás de Hidalgo.

Capello, R. (2009). Regional Growth and Local Development Theories: Conceptual Evolution over Fifty Years of Regional Science. Géographie, Économie, Société 11(1), 9-21.

CEPAL (2009). Economía y Territorio en América Latina y el Caribe: Desigualdades y Políticas. Santiago de Chile: Naciones Unidas.

Contreras, D., Larrañaga, O., Litchfield, J., and Valdés, A. (2001). Poverty and income distribution in Chile 1987-1998.: New evidence. Cuadernos de economía 38(114), 191-208.

Cuadrado-Roura, J. R., and Aroca, P. (2013). Facing the need for regional policies in Latin America. In J. R. Cuadrado-Roura and P. Aroca (Eds.). Regional Problems and Policies in Latin America. Springer, 21-42.

Delgado, A., and Del Pozo Segura, J. M. (2011). Convergencia y Ciclos Económicos Departamentales en el Perú: 1979-2008. Lima: Consorcio de Investigación Económica y Social y 
Pontificia Universidad Católica del Perú. Investigación CIES 2011.

Delgado, A., and Rodríguez, G. (2015). Structural Breaks and Convergence in the Regions of Peru: 1970-2010. Review of Development Economics 19(2), 346-357.

Delgado, A., and Rodríguez, G. (2017). Convergencia en las Regiones del Perú: ¿Inclusión o Exclusión en el Crecimiento de la Economía Peruana (1970-2010)? In P. Francke and J. Rodriguez (Eds.). Exclusión e Inclusión Social en el Perú. Lima: Pontificia Universidad Católica del Perú, 249-294.

Di Filippo, A. (2019). The Structuralism of Prebisch and the Integration of Latin America. In V. R. Fernández and G. Brondino (Eds.). Development in Latin America: Critical Discussions from the Periphery. Springer, 215-235.

Durlauf, S. N. (2006). Groups, social influences, and inequality. In D. Bowles and K. Hoff (Eds.). Poverty Traps. New York: Princeton University Press, 141-175.

Frigolett, H. (2013). Economías regionales en Chile: desigualdad y heterogeneidad. Documentos de trabajo RIMISP 12, Serie Estudios Territoriales: Santiago de Chile: RIMISP - Centro Latinoamericano para el Desarrollo Rural.

Galvis, L. A., and Meisel, A. (2001). El crecimiento económico de las ciudades colombianas y sus determinantes, 1973-1998. Coyuntura Económica 31(1), 69-90.

Galvis, L. A., and Meisel, A. (2013). Regional Inequalities and Regional Policies in Colombia: The Experience of the Last Two Decades. In J. R. Cuadrado-Roura and P. Aroca (Eds.). Regional Problems and Policies in Latin America. Springer, 197-223.

Gasparini, L., and Lustig, N. (2011). The Rise and Fall of Income Inequality in Latin America. La Plata: Centro de Estudios Distributivos, Laborales y Sociales, Universidad Nacional de La Plata. Working Paper 118.

Gonzales de Olarte, E. (1982). Las Economías Regionales del Perú. Lima: Instituto de Estudios Peruanos.

Gonzales de Olarte, E. (2015). Una Economía Incompleta, Perú 1950-200\%. Un Análisis Estructural. Lima: Fondo Editorial de la Pontificia Universidad Católica del Perú.

Gonzales de Olarte, E., and Del Pozo, J. M. (2012). Lima, a polycentric city. An analysis from the location of employment. Journal of Regional Research 23, 29-52.

Gonzales de Olarte, E., and Del Pozo, J. M. (2018). El espacio importa para el desarrollo humano: El caso peruano. Departamento de Economía - Pontificia Universidad Católica del Perú. Working Paper 462.

Gonzales de Olarte, E., and Trelles Cassinelli, J. (2004). Divergencia y Convergencia Regional en el Perú: 1978-1992. Economía 27(53-54), 35-63.

González, R. V., Servían, J. M., and Martínez-Lara, A. (2010). Crecimiento económico y convergencia regional en el Estado de México. Paradigma Económico 2(1), 53-88.

Heckscher, E. F. (1919). The effect of foreign trade on the distribution of income. Readings in the Theory of International Trade , 272-300.

Hernández-Vásquez, A., Azañedo, D., Antiporta, D. A., and Cortés, S. (2017). Análisis espacial de la anemia gestacional en el Perú, 2015. Revista Peruana de Medicina Experimental y Salud Pública 34, 43-51. 
Hernández-Vásquez, A., Bendezú-Quispe, G., Díaz-Seijas, D., Santero, M., Minckas, N., Azañedo, D., and Antiporta, D. A. (2016). Análisis espacial del sobrepeso y la obesidad infantil en el Perú, 2014. Revista Peruana de Medicina Experimental y Salud Pública 33, 489-497.

Hernández-Vásquez, A., and Tapia-López, E. (2017). Desnutrición crónica en menores de cinco años en Perú: Análisis espacial de información nutricional, 2010-2016. Revista Española de Salud Pública 91, 1-10.

Herrera, P. (2009a). Aproximando el clima de negocios a nivel municipal. Lima: Departamento de Economía - Pontificia Universidad Católica del Perú. Working Paper 276.

Herrera, P. (2009b). Perú: Propuesta de redistribución de los recursos del canon y regalías mineras a nivel municipal. Economía 32(64), 45-82.

Hoyt, H. (1954). Homer Hoyt on development of economic base concept. Land Economics 30(2), $182-186$.

Isserman, A. M. (1995). The history, status, and future of Regional Science: An American perspective. International Regional Science Review 17(3), 249-296.

Katz, I. M. (1998). La apertura comercial y su impacto regional sobre la economía mexicana. México: Miguel Ángel Porrúa - Instituto Tecnológico Autónomo de México.

Krugman, P. R. (1991). Geography and trade. Cambridge: MIT press.

LeSage, J. P. (1997). Bayesian estimation of spatial autoregressive models. International Regional Science Review 20(1-2), 113-129.

Lustig, N. C. (2010). Coping with austerity: Poverty and inequality in Latin America. Washington D.C.: Brookings Institution Press.

Marshall, A. (1920). Principles of Economics. London: Mcmillan.

Messmacher, M. (2000). Desigualdad regional en México. El efecto del TLCAN y otras reformas estructurales. Research Document 2000-4, Banco de México.

MINAM (2014). Estrategia Nacional de Diversidad Biológica al 2021 (Plan de Acción 20142018). Sistema Nacional de Información Ambiental. Lima: Perú.

MINDES (2019). Informe de Desarrollo Social 2019. Santiago de Chile: Ministerio de Desarrollo Social y Familia.

North, D. C. (1955). Location Theory and Regional Economic Growth. Journal of Political Economy 63(3), 243-258.

OECD (2009). Territorial review: Chile. Paris: OECD Publishing.

Ohlin, B. (1935). Interregional and international trade. Cambridge: Harvard University Press.

Paelinck, J. (1978). Spatial econometrics. Economics Letters 1(1), 59-63.

Palomino, J., and Rodríguez, G. (2019). Peru's Regional Growth and Convergence in 19792017: An Empirical Spatial Panel Data Analysis. Departamento de Economía - Pontificia Universidad Católica del Perú. Working Paper 478.

Paredes, D., Iturra, V., and Lufin, M. (2016). A spatial decomposition of income inequality in Chile. Regional Studies 50(5), 771-789.

Paulson, S. (2011). Pautas conceptuales y metodológicas: género y dinámicas territoriales. Santiago de Chile: RIMISP - Centro Latinoamericano para el Desarrollo Rural. Documento 
de trabajo/Programa Dinámicas Territoriales Rurales 84 .

Perroux, F. (1970). El teorema Heckscher-Ohlin-Samuelson. Investigación Económica 30(120), 621-645.

Pulgar Vidal, J. (1946). Historia y geografía del Perú: Las ocho regiones naturales del Perú, vol. 256. Lima: Fondo Editorial de la Universidad Nacional Mayor de San Marcos.

Romer, P. M. (1986). Increasing returns and long-run growth. Journal of Political Economy 94(5), 1002-1037.

Sánchez, A. (2017). Migraciones Internas en el Perú. Lima: Organización Internacional para las Migraciones.

Sastré-Gutiérrez, M. L., and Rey, S. J. (2008). Polarización espacial y dinámicas de la desigualdad interregional en México. Problemas del desarrollo 39(155), 181-204.

Sinclair, R. (1967). Von Thünen and Urban Sprawl. Annals of the Association of American Geographers 57(1), 72-87.

Sutton, M. B., Lindow, G., Serra, M. I., Ramirez, G., and Pazmino, M. F. (2006). Regional Convergence in Latin America. International Monetary Fund. Working Paper 06/125.

Tiebout, C. M. (1956). Exports and Regional Economic Growth. Journal of Political Economy 64(2), 160-164.

World-Bank (2009). Reshaping Economic Geography in Latin America and the Caribbean. Companion Volume to the 2009 World Development Report. Washington D.C.: World Bank.

Yamada, G. (2010). Migración interna en el Perú. Lima: Fondo Editorial de la Universidad del Pacífico.

Zárate, P., Durand, A., and Hernández, R. (2015). Enfoque territorial para el empoderamiento de la mujer rural - Perú. Lima: Instituto de Estudios Peruanos.

Zuñiga, J. H., and Montalvo, C. A. (2018). Dimensiones espaciales del crimen en Lima Metropolitana. Departamento de Economía - Pontificia Universidad Católica del Perú. Working Paper 451. 